\title{
Ergenlerin Atılganlık ve Sürekli Kaygı Düzeylerinin Bazı Değişkenlere Göre Íncelenmesi*
}

\section{Zöhre KAYA**, Rengin KARACA***}

Öz: Bu çalışmanın amacı, ergenlerin atılganlık ve sürekli kaygı düzeylerinin cinsiyet, sınıf ve yaş gibi değişkenlere göre farklılaşıp farklılaşmadığını incelemektir. Araştırma ilişkisel tarama modeline dayalı olarak yapılmıştır. Araştırmanın katılımcılarını İzmir iline bağlı 5 farklı meslek lisesinde okumakta olan 189 kadın, 177 erkek olmak üzere toplam 366 ergen oluşturmuştur. Araştırmanın verileri, Rathus Atılganlık Envanteri, Sürekli Kaygı Envanteri ve Kişisel Bilgi Formu aracılığıyla toplanmıştır. Analizlerde, betimsel istatistikler, "t-testi”, "tek yönlü varyans analizi” ve korelasyon analizi teknikleri kullanılmıştır. Elde edilen bulgulara göre, ergenlerin atılganlık düzeyi ile sürekli kaygı düzeyi arasında negatif yönde anlamlı ilişki olduğu görülmüştür. Cinsiyete göre bakıldığında; kadınların sürekli kaygı düzeyinin anlamlı olarak erkeklerden daha yüksek olduğu, atılganlık düzeyi açısından ise anlamlı fark olmasa da erkeklerin ortalamalarının kadınlardan yüksek olduğu bulunmuştur. Sonuçlar; 12. sınıf öğrencilerinin atılganlık düzeylerinin anlamlı olarak 9. sınıf öğrencilerinden yüksek olduğunu, 17 yaş grubundaki öğrencilerin 15 yaş ve 16 yaş gruplarındaki öğrencilere oranla daha yüksek atılganlık düzeyine sahip olduklarını ortaya koymuştur. Araştırmadan elde edilen bulgular ilgili alanyazın ışığında tartışılarak öneriler sunulmuştur.

Anahtar Kelimeler: Atılganlık, Kaygı, Saldırganlık, Çekingenlik, Sürekli-Durumluluk Kayg1, Ergen

\footnotetext{
*Bu çalışma yazarın "Meslek Lisesi Öğrencilerinin Atılganlık ve Sürekli Kaygı Düzeylerinin Karşılaştırılması Üzerine Bir Araştırma" başlıklı lisansüstü tez çalışmasının bir bölümünden üretilmiştir.

***Dr. Öğrt. Üyesi. Van Yüzüncü Yıl Üniversitesi, Eğitim Fakültesi, Eğitim Bilimleri Bölümü, Rehberlik ve Psikolojik Danışmanlık Anabilim Dalı. Email: zohrekaya@ yyu.edu.tr, Orcid ID: 0000-0001-9211-3632.

***Prof. Dr. Dokuz Eylül Üniversitesi, Buca Eğitim Fakültesi, Eğitim Bilimleri Bölümü, Rehberlik ve Psikolojik Danışmanlık Anabilim Dalı. Email: rengin.akboy@deu.edu.tr, Orcid ID: 0000-0001-5955-0603
} 


\section{Investigating Adolescents' Assertiveness and Trait Anxiety Levels Based on Certain}

\section{Variables}

Abstract: The aim of the present study was to investigate whether the assertiveness and trait anxiety levels of adolescents differ based on certain variables such as gender, grade and age. The study was designed as a relational screening model. The participants of the study consisted of total 366 adolescents (189 females, and 177 males) who were enrolled in 5 different vocational high schools in İzmir province. The data were collected via Rathus Assertiveness Inventory, Trait Anxiety Inventory and Demographic Information Form. Descriptive statistics, t-test, one-way ANOVA and regression analyses were used. The results indicated that there was a significant negative correlation between the assertiveness and trait anxiety scores of adolescents. When compared according to gender, females were found to have higher trait anxiety scores compared to males. Even no significant difference was found, males had higher mean scores on assertiveness. The results also showed that $12^{\text {th }}$ grade students have significantly higher assertiveness levels compared to $9^{\text {th }}$ grade students. Also 17-year-old students were found to have higher assertiveness levels compared to students both 15 and 16 years old. The results were discussed within the framework of the related literature and suggestions were presented.

Keywords: Assertiveness, Anxiety, Aggression, Shyness, Trait-State Anxiety, Adolescent

\section{Giriş}


İnsan davranışını anlama ve açıklama çabası bir davranış bilimi olarak psikolojinin geçmişten bu yana üzerinde durduğu en temel konulardan birisidir. Davranış, kişiliğin bir yansıması olarak düşünüldüğünden, davranış biçimi de bireyin hangi kişilik eğilimlerine sahip olduğunun bir göstergesi olarak kabul edilir. Kendi hakkını arayamayan, toplumsal ilişkilerde kendini ortaya koyamayan bireylerin durumu; davranış terapisi alanı içerisinde Wolpe (1958) ve Salter'ın (1949) üzerinde çalıştığı dönemlerden bu yana, psikolojinin inceleme alanlarından birisi olmuştur. Başlangıçta, belirli karakter özelliklerine sahip bireylerin haklarının korunması amacıyla ortaya çıkan atılganlık becerisi, terapi alanlarına daha çok bu bireylerin hayatlarında daha etkili olabilmelerine katkı sağlayacak bir girişim anlamı ile konu olmuştur (Akt; Kılkus, 1993). Bu bağlamda kimi insanları atılgan, kimilerini de çekingen kılan nedenler nelerdir? Atılganlık becerisi, bireylerin günlük ilişkilerin de etkili olmalarına yardımcı olma anlamında bir teşebbüs ifade eder mi? gibi soruların tartışılmasıyla atılganlık kavramı şekillenmiştir.

Atılganlık kavramının açıklanmasında farklı teorik yaklaşımlardan yararlanıldığı görülmektedir. Bu yaklaşımların atılganlık kavramını değişik boyutlarla ele aldıkları ve tek bir bakış açısından ziyade çok yönlü değerlendirdikleri dikkat çekmektedir. Bu nedenle birçok araştırmacının vurguladığı gibi (Galassi ve Galassi, 1978; Gambrill ve Richy, 1975) atılganlık tek bir kişilik özelliği olmaktan çok öğrenilmiş, duruma özel bir dizi sözel ve sözel olmayan davranışlar örüntüsü olarak formüle edilebileceği; çok yönlülük anlayışına uygun olarak bazı öğeleri kapsayacağı belirtilmektedir (Akt; Tegin, 1990). Bu öğeler, bireyin davranışsal, durumsal ve kişisel ilişki boyutlarını içermektedir.

Atılgan olma ya da olmama durumu, bireyin grupla ilişkisini etkilediğinden, atılganlık kavramının sosyal psikoloji açısından açıklanma ihtiyacını ortaya koymuştur. Wills, Baker ve Botvin'de (1989), atılganlığın çok boyutlu bir yaklaşımla ölçülmesinin bir ihtiyaç olduğunu değerlendirmişlerdir. Bu bakış açısı, Floyd Allport'un bireyin grupla ilişkisinin sosyal 
psikolojinin “esas meselesi” olarak düşünülmesi gerektiği yönündeki bilgisiyle bütünlük kazanmaktadır (Vanbeleare, 1996). Nitekim, çok yönlü ve sosyo-kültürel doğası çerçevesinde araştırılan atılganlık kavramı (Tegin, 1990), çok sayıda çalışmada kuramsal açıklamalar doğrultusunda özellikle de cinsiyet ve kültürel faktörlerle ilişkili olarak incelenmiştir.

Atılganlık; Alberti ve Emmons (1986) tarafından, kişinin anksiyete yaşamadan kendi başına ayakta durmasını, duygularını daha rahat ifade etmesini, başkalarının haklarını göz ardı etmeden kendi değer ve ilgilerine uygun davranmasını mümkün kılan kişilerarası davranış olarak tanımlanmıştır. Alanyazında atılganlık kavramının zaman zaman saldırganlık, baskınlık (Dominance) ve otoriteryanizm gibi kavramlarla karıştırıldığı ve bu kavramlar arasında net bir ayrımın yapılamadı̆̆ı görülmektedir. Yine davranış bilimciler ve araştırmacılar genellikle atılgan ve saldırgan davranış konusunda karmaşaya düştüklerini kabul etmektedirler. Bu nedenle Tucker ve Weaver (1983) tarafından dikkat çekildiği üzere; bu iki kavram tanımsal açıdan netlik kazanmaz ise günlük hayatta doğal olarak atılgan davranış, saldırgan davranış olarak etiketlenemeye devam edebilir. Otoriteryanizm kavramının da atılganlık yerine yanlış kullanıldığı; ancak, atılganlığın saldırgan olmayan baskınlık olarak değerlendirilmesi gerektiği vurgulanmıştır. Bu konuyla ilgili çalışma yapan Ray (1986), kendini sosyal olarak kabul ettiren bireyleri atılgan, ettirmeyen bireyleri ise otoriteryan olarak değerlendirmek gerektiği sonucuna varmıştır. Atılganlık kavramının tanımını netleştirmek gerekirse, bireyin kendi haklarının başkaları tarafından ihlal edilmesi durumunda buna karşı koyup, kendisini savunamaması çekingenlik olarak tanımlanmaktadır. Saldırganlık ise kişinin kendi haklarını başkalarının haklarını ihlal ederek, kendi düşünce, duygu ve inançlarını açık ve gerçekçi olmayan yollarla belirtmesidir. Atılganlık kişilik özelliği, kişinin kendi haklarını başkalarının haklarına da saygı duyarak savunması, kendi duygu, düşünce ve inançlarını açık, gerçekçi ve uygun iletişim yolları kullanılarak açıklamasıdır. 
Kişilerarası ilişkilerde temel bir uyum öğesi olarak değerlendirilen atılganlık kavramının, sosyal beceri bağlamında da önemli olduğu aktarılmaktadır (Tegin, 1990). Smith’e göre (1998), sosyal ilişkilerde güvengen olmak; kişinin bir başkasına kim olduğunu, ne yaptığını, ne istediğini ve yaşamdan ne beklediğini iletebilmesidir. Buna paralel olarak olumlu bir davranış biçimi olarak atılganlığın dört yeteneği gerektirdiği belirtilmiştir (Lazarus, 1973). Bunlar; hayır diyebilme, isteyebilme ve ricada bulunabilme, olumlu ve olumsuz duyguları ifade edebilme ile bir davranışı başlatabilme, sürdürebilme ve sonlandırma yeteneği olarak sıralanmıştır. Liberman ve arkadaşları (1978), atılganlık kavramının uluslararası alanyazında kişisel etkililik (Personel Effectiveness) olarak da yer aldığını belirtmişlerdir (Akt: Acar ve Whirter, 2000; s. 144).

Kendine güveni az olan, benlik kavramı olumsuz yönde gelişmiş, kendi haklarını koruyamayan ve bunun gerekliliğinin bilincinde olmayan bireylerin, eksik olan bu yönlerini gidermeleri için nerede, nasıl ve neler yaparak atılgan olunabileceğini göstermek amacıyla atılganlık eğitimi programı geliştirilmiştir. Herhangi bir kişinin ya da grubun atılgan ve çekingen davranabilme derecesini belirlemek amacıyla kullanılan Rathus Atılganlık Envanteri'nin (RAE) uygulanması sonucunda -90 ile +10 arasında puan alan kişiler çekingen davranış biçimine sahip olduğu için atılganlık eğitimine alınmaktadır. Sosyal beceri olarak atılganlık eğitiminin daha çok saldırganlığı ve sözel tacizi önlemede, çeşitli psikiyatrik vakaların tedavisinde, kronik ağlama nöbetlerini azaltmada ve çekingenliğin üstesinden gelmek için çok sayıda araştırmada kullanıldığı bildirilmiştir (Del Greco ve diğ., 1986).Aynı zamanda, kişilerarası kaygıyı ve stresin psikolojik semptomlarını azaltmak için bazı yazarlar tarafından kullanılması önerilmiştir (William ve Stout, 1985). Atılganlık kavramının çalışıldığı araştırmalara bakıldığında özsaygı, özgüven, kendini kabul düzeyi, kişilerarası ilişkiler ve bireysel memnuniyet durumunun sosyal becerilerde bireye atılgan olma yönünde katk1 
sağladığı yönünde ortak görüş olduğu dikkat çekmektedir. Pek çok çalışma atılganlığın önemli bir beceri olduğunu göstermiştir (Delamater ve Mcnamara, 1985).

Bireyin kişilerarası ilişkilerde yaşadığı duygulardan birisi de pek çok ortamda yaşadığı kaygı durumudur. Kaygı, kişinin hayatında dönem dönem yaşadığı ve gelecek yaşamda da güçlük içine gireceği olaylarla karşılaşma düşüncesi ile şekillenen güvensizlik, kararsızlık ve çatışma hissettiği durumlar karşısında gösterdiği tepkidir (Akyıldız, 1987).Bir çok kuramcının üzerinde birleştiği kaygıya yol açan nedenler; bireyin yetişmesinde rolü olan psiko-sosyal ilişkiler, anneden çocuğa empati yoluyla geçen kaygı, hatalı anne-baba tutumları, bağımsızlık tanımayan, bağımlılığı, destekleyen aşırı koruyucu ve denetleyici aile tutumları, ebeveynin yüksek beklentisi, anne baba tarafından kullanılan uygunsuz ceza yöntemleri, sosyal desteğin eksikliği, zorlayıcı yaşantılar vb. şeklinde sıralanabilir (Geçtan, 1993; Onur, 1993; Öztürk, 1994; Yanbast1, 1994).

Kaygının davranışlar üzerindeki etkisi kuramcılar tarafından farklı açıklanmıştır. Kaygıyı egonun bir işlevi olarak tanımlayan Freud, 1926'da “Ketlemeler, Belirtiler ve Kaygı” adlı eseriyle bu duygunun psikolojik bir olgu olduğunu ortaya koymuştur (Geçtan, 1993). Freud'un “anksiyete sorunu, birçok önemli sorunun bir araya toplandığı bir düğüm noktası ve çözümü tüm ruhsal varlığımıza 1şık tutacak bir bulmacadı»" (Geçtan, 1993) şeklindeki tanımı; anksiyete konusunun, psikoloji içinde ne kadar önemli ve hayati bir yer taşıdığını göstermektedir. Kişiler arasındaki ilişkiler üzerine yaptığı çalışmalarla bilinen Sullivan, anksiyete kavramını insan varlığının "ortak yıkıcı yanı” olarak tanımlar. Ona göre anksiyete, bireyin diğer insanlarla ilişki ve iletişim kurmasını engelleyen başlıca etmendir (Yanbastı, 1994). Freud, doyum elde edilemeyen yaşantıların anksiyeteye yol açtığını; diğer bir kuramcı olan Horney ise anksiyetenin küçük yaşlarda çocuğun kabul görmemiş olmasından kaynaklandığını belirterek, temel anksiyetenin çevre ilişkilerinden dolayı ortaya çıktığını ileri 
sürmüştür. Horney, Freud'un aksine cinsel içgüdülerin anksiyeteyi fazla etkilemediğine inanır (Yanbast1, 1994).

Alanyazında atılganlık ve kaygı üzerinde yapılmış çok sayıda araştırma bulunmasına karşın birlikte çalışıldığı araştırma sayısı oldukça azdır.Yaşamlarının en hassas döneminde bulunmaları gerçeğinden hareketle, kaygı ve dolayısıyla toplumla uyum sorunu yaşamaya yatkın olan ergenlerin kabul görmeyen davranışlarının toplumsal ilişkilerde yaşadıkları sosyal beceri eksikliğinden kaynaklandığı düşünülmektedir (Hurt, 1986). Atılganlık, sosyal beceri olarak tanımlandığı için, ileri sürülen bu görüşler temelinde benlik kavramı zayıf ve ilişkilerde olumsuz duygular içinde olan bireylerin atılgan olması beklenemeyeceği gibi toplumsal uyum konusunda zorluk yaşamaları olasıdır.

Ergenlerin kendilerini atılgan biçimde ifade etmesini önleyen nedenlerin ve kayg1 alanlarının belirlenmesi, kaygı ve atılgan davranış arasındaki ilişkinin bireysel ve toplumsal değişkenler açısından ele alınıp incelenmesinin, ergenlere günlük yaşamlarındaki uyumuna ve etkili olmasına yönelik pratik anlamda katkı sağlayabilir. Eğer kaygının farklı etkileri tanımlanabilir ve bunlar ergenin çevresi tarafından kontrol edilebilinirse ergenlerin kendilerine güvenlerini geliştirip, sosyal beceriler kazanmalarına yardımcı olma olanağı olabilir. Nitekim konu ile ilgili araştırma sonuçları atılgan davranışın, uygun sosyal beceri ve davranış özelliklerinin eğitimle kazanılabileceğini göstermiştir. Bu bilgiler 1şığında bu çalışmada, ergenlerin atılganlık ve kaygı düzeyleri arasındaki ilişkiyi ortaya koymak ve bu özelliklerin cinsiyet, sınıf, bölüm, yaş vb. değişkenlere göre anlamlı bir farklılık gösterip göstermediğinin araştırılması amaçlanmıştır.

\section{Yöntem}

\section{Araştırmanın Deseni}


Bu çalışma, iki ya da daha çok sayıdaki değişken arasındaki birlikte değişimin varlığını ve derecesini incelemeyi amaçlayan ilişsisel tarama modeline dayanmaktadır.

\section{Araștırmanın kalıtımcıları}

Araştırmanın katılımcıları İzmir iline bağlı 5 farklı meslek lisesinde okumakta olan \%51.6’s1 (n:189) kadın, \%48.4’ü (n:177) erkek olmak üzere toplam 366 öğrenciden oluşmuştur. İzmir Milli Eğitim Müdürlüğü’nden alınan izinle yapılan çalışma \%50,8 (n:186) birinci sınıf, \%49,2 (n:180) son sınıf öğrencisi ile yürütülmüştür. Yaşları 14 ve 19 arasında değişen öğrencilerin ailelerinin sosyo-ekonomik durumuna ilişkin algılarına göre dağılımlarına bakıldığında, \%84.7'sinin (n:310) orta, \%10.9'unun (n:40) düşük ve \%4.4'ünün (n:16) ise yüksek olarak tanımladıkları görülmüştür. Öğrencilerin \% 3'nün (n=11) tek çocuk oldukları, $\% 49.5 ' \operatorname{nin}(\mathrm{n}=181)$ bir kardeş, \%25.7'sinin $(\mathrm{n}=94)$ iki kardeş ve \%21.6'sının $(\mathrm{n}=79)$ üç ve üstünde kardeş sahibi oldukları görülmüştür.

\section{Veri Toplama Araçları ve Uygulanması}

Rathus Atılganlık Envanteri (RAE). Kişiler arası ilişkilerde atılganlık ve çekingenlik düzeylerini ölçmek amacıyla Rathus (1973) tarafından geliştirilen RAE ,Voltan (1980) tarafından Türkçe'ye uyarlanmıştır. Voltan'ın yaptığı çalışmada, ölçeğin test-tekrar test güvenirliği 0.92, iki yarı test güvenirliği 0.77 ve ölçüt bağımlı geçerlik çalışmasında korelasyon katsayısı 0.70 olarak bulunmuştur. RAE, 13 olumlu $(3,6,7,8,10,18,20,21,22$, $25,27,28,29)$ ve 16 olumsuz $(1,2,4,5,9,11,12,13,15,16,17,19,23,24,26,30)$ ifade olmak üzere toplam 30 maddeden oluşmaktadır. Olumsuz ifadeler ters kodlanarak puanlanmaktadır. Birey kendisini +3'den -3'e doğru değişen 6 dereceli bir ölçekle değerlendirmektedir. Alınan puanlar -90 ile +90 arasında değişmekte olup; -90 puan en yüksek derecede çekingenliği, +90 puan ise en yüksek düzeyde atılganlığı gösterir. +10 puan ve yukarısındaki puanlar atılganlığı, altındaki puanlar ise çekingenliği ifade etmektedir. (Öner, 2006). 
Sürekli Kaygı Envanteri (SKE). Spielberg ve arkadaşları (1970) tarafından 14 yaş ve üstündeki gençler ve yetişkinlerdeki sürekli ve durumluk kaygı düzeylerinin ölçülmesi amacıyla geliştirilen ölçek Türkçeye Öner ve Le Compte (1983) tarafından uyarlanmıştır. Bu çalışmada envanterin Sürekli Kaygı boyutu kullanılmıştır. Kısa cümlelerden oluşan bir özdeğerlendirme anketi olan SKE, 20 maddeden oluşmakta ve 1-4 arası derecelenmektedir. Alınan puanlar 20 ile 80 arasında değişmekte ve puanların yüksekliği kaygının yüksekliğini göstermektedir. Ölçekte 3'den fazla madde yanıtlanmamışsa ölçek puanlamaya dahil edilmez. Ölçeğin normal ve hasta örneklemleriyle yapılan çalışmalar sonucu elde edilen güvenirlik katsayıları .83 ile .87 arasında; test tekrar test tekniği ile güvenirlik katsayıları sürekli kaygı ölçeği için .71 ile .86 arasında bulunmuştur (Öner, 2006).

Kişisel Bilgi Formu (KBF).Katılımcıların cinsiyet, sınıf, bölüm, yaş, kardeş sayısı, anne-baba eğitim düzeyi, ailenin sosyo-ekonomik düzeyi, okul türü ile ilgili bilgiler araştırmacı tarafından oluşturulan bir bilgi formu aracılığıyla toplanmıştır.

\section{Verilerin Analizi}

Veri analizine başlamadan önce veri setinin gerekli varsayımları karşılayıp karşılamadığ1 test edilmiş, veri setinin normal dağılım gösterdiği görülmüştür. Verilerin analizinde betimsel istatistikler (frekans dağılımı, aritmetik ortalama, standart sapma), atılganlık ve kaygı düzeylerinin bağımsız değişkenlerle karşılaştırılmasında iki grup olduğu durumlar için "t-testi”, ikiden fazla grupların olduğu durumlar için “tek yönlü varyans analizi”, değişkenler arasındaki ilişkilerin belirlenmesi için korelasyon analizi kullanılmıştır.

\section{Bulgular}


Araştırmaya katılan öğrencilerin Atılganlık Ölçeği ve Sürekli Kaygı Ölçeği'nden almış oldukları puanlara ilişkin aritmetik ortalama, standart sapma ve minimum-maksimum değerler Tablo 1'de verilmiştir.

Tablo 1

RAE ve SKE'den elde edilen puanlara ilişkin betimleyici istatistikler

\begin{tabular}{|c|c|c|c|c|c|}
\hline Değişkenler & $\mathrm{n}$ & $\bar{X}$ & SS & Minimum & Maksimum \\
\hline $\begin{array}{l}\text { Atılganlık } \\
\text { Düzeyi }\end{array}$ & & 21.36 & 20.99 & -35 & +72 \\
\hline $\begin{array}{l}\text { Sürekli Kaygı } \\
\text { Düzeyi }\end{array}$ & 366 & 43.06 & 8.4 & 14 & 67 \\
\hline
\end{tabular}

Tablo 1'de görüldüğü gibi, araştırmaya katılan ergenlerin, atılganlık ölçeği puan ortalamaları $(21.36 \pm 20.99)$ ve sürekli kaygı ölçeği puan ortalamaları (43.06 \pm 8.4$)$ olarak belirlenmiştir. Buna göre, öğrencilerin atılganlık düzeylerinin düşük, kaygı düzeylerinin ise orta düzeyde olduğu söylenebilir.

Katılımcıların Atılganlık Ölçeği’nden aldıkları puanlarla Sürekli Kaygı Ölçeği'nden aldıkları puanların cinsiyet ve sınıf değişkenlerine göre farklılaşıp farklılaşmadığını belirlemek üzere yapılan bağımsız grup t testi sonuçları Tablo 2'de verilmiştir.

Tablo 2

RAE ve SKE'den elde edilen puanların cinsiyet ve sınıf değişkenlerine göre $t$ testi sonuçları

\begin{tabular}{lccccccccccc}
\hline & \multicolumn{1}{c}{ SKE Puanları } & \multicolumn{8}{c}{ RAE Puanları } \\
Değișkenler & $\mathbf{n}$ & $\bar{X}$ & $\mathbf{s s}$ & $\mathbf{t}$ & $\mathbf{p}$ & $\mathbf{n}$ & $\bar{X}$ & $\mathbf{s s}$ & $\mathbf{t}$ & $\mathbf{p}$ \\
\hline Cinsiyet & & & & & & & & & & \\
Kadın & 189 & 45.24 & 8.6 & 5.29 & .000 & 189 & 20.98 & 20.2 & -0.36 & .718 \\
Erkek & 177 & 40.74 & 7.5 & & & 177 & 21.77 & 21.7 & & \\
Sinıf & & & & & & & & & & \\
9. sinıf & 186 & 42.59 & 8.6 & -1.1 & .272 & 186 & 18.61 & 20.2 & -2.57 & .01 \\
12. sinıf & 180 & 43.56 & 8.2 & & & 180 & 24.21 & 21.4 & & \\
\hline
\end{tabular}


Tablo 2'de görüldüğü gibi, ergenlerin atılganlık ve sürekli kaygı düzeylerinin cinsiyet değişkenine göre anlamlı farklılık gösterip göstermediğini belirlemek için yapılan bağımsız grup t testi sonucunda, sürekli kaygı düzeyinin istatistiksel açıdan anlamlı bir farklılık gösterdiği saptanmıştır $[\mathrm{t}=5.29, \mathrm{p}<.05]$. Buna göre kadınların sürekli kaygı düzeyleri $(\bar{X}=$ 45.24) erkeklerin sürekli kaygı düzeylerinden $(\bar{X}=40.74)$ daha yüksek olduğu bulunmuştur. Atılganlık puanları açısından bakıldığında, erkeklerin atılganlık puan ortalaması $(\bar{X}=21.77)$ kadınların ortalamalarından ( $\bar{X}=20.98)$ yüksek olmasına rağmen istatistiksel olarak anlamlı bir farklılık göstermemiştir (p>.05). Tablo 2 incelendiğinde, kadınların erkeklere oranla atılganlık düzeyleri düşük, kaygı düzeyleri yüksek; erkeklerin de kadınlara oranla kayg1 düzeyleri düşük, atılganlık düzeyleri daha yüksek çıkmıştır.

Tablo 2'de görüleceği üzere, ergenlerin atılganlık düzeyleri sınıf değişkenine göre anlamlı farklılık göstermektedir $[\mathrm{t}=-2.57, \mathrm{p}<.05]$. Buna göre 12. sınıf öğrencilerinin atılganlık puanları ( $\bar{X}=24.21)$ 9. sınıf öğrencilerinin atılganlık puan ortalamalarından $(\bar{X}=18.61)$ yüksek çıkmıştır. Sürekli kaygı açısından bakıldığında, anlamlı bir farklılık olmasa da 12. sınıfların ortalamaları ( $\bar{X}=43.56)$ 9. sınıf öğrencilerinin ortalamalarından ( $\bar{X}=42.59$ ) yüksek olduğu görülmüştür ( $\mathrm{p}>$.05).

Katılımcıların Atılganlık Ölçeği'nden aldıkları puanlarla Sürekli Kaygı Ölçeği’nden aldıkları puanların yaş değişkenine göre farklılaşıp farklılaşmadığını belirlemek üzere yapılan tek yönlü varyans analizi (ANOVA) sonuçları Tablo 3'de verilmiştir.

Tablo 3

RAE ve SKE'den elde edilen puanların yaş değişkenine göre tek yönlü varyans analizi (ANOVA) sonuçları

\begin{tabular}{cccccccc}
\hline Boyut & Yaş & n & $\bar{X}$ & ss & F & P & $\begin{array}{c}\text { Fark } \\
\text { (Scheffe) }\end{array}$ \\
\hline \multirow{3}{*}{ Atılganlık } & 14 & 26 & 19.00 & 21.3 & & & $15-17$ \\
& 15 & 86 & 16.87 & 19.8 & 3.08 & .01 & $16-17$ \\
& 16 & 93 & 18.76 & 20.2 & 6 & & \\
\end{tabular}




\begin{tabular}{rrrrrrll}
\hline & 18 & 58 & 23.27 & 22.7 & & \\
& 19 & 13 & 20.53 & 27.6 & & \\
\hline & 14 & 26 & 42.26 & 8.8 & & \\
Sürekli Kayg1 & 15 & 86 & 42.83 & 8.8 & & \\
& 16 & 93 & 43.18 & 8.2 & .342 & & \\
& 17 & 90 & 42.58 & 7.9 & 5 & .88 & \\
& 18 & 58 & 43.98 & 8.5 & & \\
& 19 & 13 & 44.61 & 9.7 & & \\
\hline
\end{tabular}

Tablo 3'de görüleceği üzere, ergenlerin atılganlık ve sürekli kaygı düzeylerinin yaş değişkenine göre anlamlı olarak farklılaşıp farklılaşmadığını belirlemek amacıyla yapılan tek yönlü varyans analizi (ANOVA) sonucunda, yaş gruplarının atılganlık ortalamaları arasındaki fark istatistiksel olarak anlamlı bulunmuştur $(\mathrm{F}=3,086 ; 01)$. Atılganlık puanlarının yaş değişkenine göre hangi gruplar arasında farklılaştığını belirlemek üzere yapılan tek yönlü varyans analizi (ANOVA) sonrası post-hoc değerlendirme sonucunda 15 yaş ile 17 yaş arasında 17 yaş lehine; 16 yaş ile 17 yaş arasında 17 yaş lehine istatistiksel olarak anlamlı bir farklılık saptanmıştır(p<.01). Bu sonuç, 17 yaş grubundaki öğrencilerin 15 yaş ve 16 yaş gruplarına göre daha fazla atılgan olduklarını ortaya koymaktadır. Diğer yaş grupları arasındaki farklılık istatistiksel olarak anlamlı bulunmamıştır ( $\mathrm{p}>.05)$. Sürekli kaygı düzeyi yaşa göre incelendiğinde, anlamlı bir farklılık olmasa da 19 yaş grubunun en yüksek kaygı seviyesine (44.61 \pm 9.7$), 14$ yaş grubunun en düşük kaygı seviyesine (42.26 \pm 8.8$)$ sahip olduğu görülmektedir.

Araştırmaya katılan öğrencilerin Atılganlık Ölçeği'nden aldıkları puanlarla Sürekli Kaygı Ölçeği'nden aldıkları puanlar arasındaki ilişkiyi belirlemek üzere yapılan korelasyon analizi sonuçları Tablo 4'de verilmiştir. 
Tablo 4

RAE ve SKE'den elde edilen puanlara ilişkin korelasyon analizi sonuçları

\begin{tabular}{lll}
\hline Değişkenler & \multicolumn{1}{c}{ Atılganlık Düzeyi } & Sürekli Kaygı Düzeyi \\
\hline Atılganlık Düzeyi & 1 & $-.45^{* *}$ \\
Sürekli Kayg1 Düzeyi & $-.45^{* *}$ & 1 \\
\hline $\mathrm{p}<.01$ & &
\end{tabular}

Tablo 4'den de anlaşılacağı üzere, ergenlerin atılganlık ve sürekli kaygı düzeyleri arasındaki ilişkiyi belirlemek amacıyla yapılan korelasyon analizinde, her iki ölçeğin puanları arasında istatistiksel açıdan negatif yönde anlamlı bir ilişki saptanmıştır ( $r=-.45 ; \mathrm{p}<.001)$. Buna göre, öğrencilerin atılganlık düzeyleri arttıkça kaygılarının düştüğü ya da kaygı seviyesi yükseldikçe atılganlık düzeylerinin azaldığı söylenebilir.

\section{Tartışma, Sonuç ve Öneriler}

Ergenlerin atılganlık ve sürekli kaygı düzeylerinin incelendiği bu çalışmada, katılımcıların atılganlık düzeylerinin düşük, sürekli kaygı düzeylerinin ise orta düzeyde olduğu görülmüştür (Tablo 1). Gacar ve Coşkuner (2010) güreş müsabakalarına katılan 13-17 yaş arasında bulunan toplam 110 güreşçi öğrenci ile yaptıkları çalışmada, güreşçilerin atılganlık düzeylerinin yüksek olduğu bulunmuştur. Öğrencilerin tamamının erkek olmasının bu sonuç üzerinde etkili olduğu düşünülmektedir. Ekinci ve arkadaşlarının (2013), hemşirelik öğrencileri ile yaptıkları çalışmada atılganlık puanları16.84 \pm 6.52 olarak; benzer örneklemle

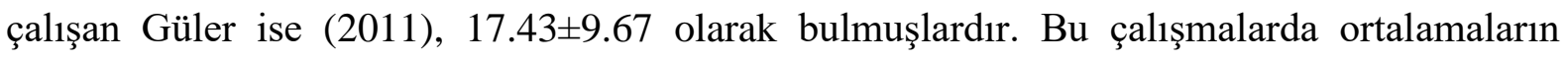
düşüklüğünün hemşirelik mesleğiyle ilişkilendirildiği; hemşirelerin çoğunlukla tepkilerini çekingen biçimde ortaya koydukları belirtilmektedir (Tan ve Aldemir, 2012). Ancak bu çalışmada öğrencilerin devam ettikleri bölümler açısından atılganlık düzeyleri anlamlı bir farklılık göstermese de ebelik bölümü öğrencilerinin en yüksek atılganlık puanına $24.93 \pm 21.0$ sahip olduğu görülmüştür. Her ne kadar alanyazında hemşirelerin geleneksel olarak atılgan olmadıklarına ilişkin bir kanı yerleşmiş olsa da bu çalışmanın bulguları bu kanıyı 
desteklememektedir. Sağlık meslek lisesi öğrencilerinin atılgan yönelime sahip olmaları; onların diğer meslek liselerine oranla iş bulma olanaklarının yüksek olması ve hemen her zaman önem taşıyan bir meslek kimliğinin öğrencilere verdiği güvenle ilişkili olduğu düşünülmektedir. Hemşirelerin atılganlık düzeyini düşük bulan bazı çalışmalarda (Farrell, 2001; Üstün, 1995), hemşireliğin bir kadın mesleği olması, kadının toplumdaki yeri, meslek doğası ve toplumun mesleğe bakış açısı ile ilişkili açıklanmalar yapılmıştır.

Bu çalışmada, ergenlerin kaygı düzeylerine ilişkin elde edilen sonucun normal olarak kabul edilen ortalamalardan biraz yüksek çıkmasının $(\bar{X}=43.06)$ ergenlik dönemi gelişim özelliklerinden kaynaklandığı düşünülmektedir. Özerklik kazanma süreci olarak bilinen ergenlik dönemi boyunca, ergenlerden yetişkinliğe hazırlanmalarını sağlayacak bazı bireysel, sosyal, duygusal ve mesleki gelişimsel ödevleri yerine getirmeleri beklenmektedir (Şahin ve Güvenç, 1996). Birey bu gelişimsel görevleri edinirken çoğunlukla kaygı duygusunu beraberinde yaşamaktadır.

Ergenlerin atılganlık düzeyleri cinsiyet değişkenine göre incelendiğinde, ortalamalar arasındaki fark anlamlı olmasa da erkeklerin atılganlık ortalamaları daha yüksek bulunmuştur. Alanyazında yer alan çok sayıda çalışma gözden geçirildiğinde, bu bulgunun bazı çalışma sonuçlarıyla uyuştuğu bazı çalışma sonuçlarıyla da tutarlılık göstermediği görülmüştür. Yapılan çalışmaların birçoğunda cinsiyet açısından farklılık bulunmamıştır (Çam ve di ̆.., 2010 ; Güven, 2010; Kapıkıran, 1993; Kessler, İbrahim ve Kahn, 1986; Kırımoğlu, 2008; Pardeck ve diğ., 1991; Sünbül ve Y1lmaz, 2008; Tan ve Aldemir, 2012;Tegin, 1990; Yaycı ve Düşmez, 2016; Yılmaz ve Sünbül, 2009). Kadın ve erkekler arasında atılganlık düzeyi açısından anlamlı farklılık olmaması; kadınların haklarını savunma, kendini ifade etme, kendine güven gibi atılgan davranışlara sahip oldukları şeklinde yorumlanmıştır (Alagül, 2004). Yılmaz ve Sünbül ise (2009), cinsiyet farklılı̆̆ının olmamasını, hızla değișen toplumsal yapıyla birlikte kadınların 
erkekler gibi toplum hayatında yerini alması ve eğitim hizmetinden eşit şekilde yararlanmasına bağlamıştır.Bir kısım araştırmada (Arı, 1989; Coşkuner ve diğ., 2013; Greco ve diğ., 1986) erkeklerin kadınlardan daha atılgan oldukları sonucuna varılmıştır. Erkeklerin atılganlığa daha yatkın olmaları toplumsal olarak erkeğe çocukluğundan itibaren her zaman daha fazla öncelik veren bir cinsiyet anlayışının olması ve aile içi tutumlarla ilişkilendirilebilinir. Russell ve Russell (1987), özellikle babaların erkek çocuklarının yanlışlarına daha duyarlı davrandıklarını ve bağımlı davranışlarına olumsuz tepkide bulunduklarını belirtmiştir. Böylece erkek çocuklar bağımsız, atılgan davranmayı öğrenmek zorunda kalmaktadırlar. Kültürel özellikler çerçevesinden bakıldığında kadınların atılganlık düzeylerinin daha düşük olacağı öngörülmektedir. Ancak alanyazın bu konuda farklı sonuçlar ortaya koymaktadır.Yapılan bazı çalışmalarda (Abakay ve diğ., 2017; Adana ve diğ., 2009; Ekinci ve diğ., 2013; Güler, 2011; Kırımoğlu ve diğ., 2009; Top ve Kaya, 2009) kadınların ortalamaları daha yüksek çıkmıştır. Her ne kadar atılganlık özellikleri daha çok erkeklere özgü olarak değerlendirilmiş olsa da yapılan çalışmalar bu kanının her zaman geçerli olmadığını göstermektedir.Tegin (1990), cinsiyetle ilgili bulgulardaki tutarsızlığın atılganlığın sosyo-kültürel etkenlere bağlı olmasından kaynaklandı̆̆ını belirtmiştir.

Cinsiyete göre atılganlık ve kaygı ortalamaları arasındaki negatif ilişkiye bakıldığında, elde edilen bulgular ergenlerde aile ve benlik algısı ile ilgili yürütülmüş olan ve kadınlar için duygusal yakınlığın, erkekler için atılganlığın ve kendini savunmanın daha önemli olduğu sonucunu elde eden Şahin ve Güvenç’in (1996) çalışmalarını desteklemektedir. Bu bulgular erkeklerin kadınlara oranla daha az kaygılı ve daha atılgan olmaları çerçevesinde değerlendirildiğinde, kadın ve erkeğin toplum içinde yetiştirilme tarzı, toplumun bakış açısı gibi cinsler arasında doğabilecek potansiyel farklılıklar göz önüne alınmalıdır. Çünkü kadınlar, geleneksel olarak atılgan bir şekilde kendini anlatma (Bloom, Coburn ve Pearlman, 1976. Akt; 
Cooley ve Nowisk1, 1984) ve atılgan davranma yönünde ödüllendirilmemektedir. Bu durum kadın ve erkekler arasındaki farklılığın temel kaynağıdır. Cooley ve Nowiskı (1984), tarafindan yapılan çalışma, erkekler için yüksek atılganlık ve düşük kaygı arasında önemli korelasyon olduğunu göstermiştir. Kadınlar için bunun tersi bir ilişki bulunmuştur. Çünkü atılgan davranış özellikle erkeklerde cesaretlendirilmiştir. Kılkus'un (1993) öne sürdüğü üzere, bir kişinin cinsiyeti, kişinin atılganlık düzeyini basitçe etkileyebilir. Çünkü kadın ve erkeğin toplumsallaşma süreci farklıdır.Yılmaz ve Sünbül'e göre (2009), geleneksel cinsiyet rollerinin benimsenmesinin, kadınları erkeklere bağımlı kılmakta ve bu durumda pek çok kadının sosyal konumunun erkekler tarafından belirlenmesine yol açmaktadır.

Ergenlerin kaygı düzeylerinin cinsiyete göre farklılaştığı, kadınların ortalamalarının daha yüksek olduğu görülmüştür. Cinsiyet kaygı ilişkisini araştıran çok sayıda çalışmada (Akboy, 1990; Sargın, 1990; Boyacı, 1990) kadınların kaygı düzeyi erkeklerden daha yüksek bulunmuştur. Kaya, İkiz ve Asıcı (2016) tarafından fen lisesi öğrencileriyle yapılan çalışmada kadınların kaygı düzeylerinin erkeklerden daha yüksek olduğu bulunmuştur.Yapılan başka bir çalışmada (Nacar ve diğ., 2011), sürekli kaygı puanı cinsiyete göre anlamlı farklılık göstermemiştir.

Öğrencilerin atılganlık düzeyleri sınıf değişkenine göre incelendiğinde, 12. sınıfların atılganlık düzeylerinin 9. sınıflardan yüksek olduğu görülmüştür. Bu sonucun, yaşın ilerlemesi ile birlikte bireylerin yaşama dair bilgi ve deneyimlerinin artmasıyla ilgili olduğu düşünülmektedir. Son sınıfların daha kendilerine güvenli, deneyimli ve kimlik olayını daha fazla çözmüş olmalarının etkisi bulunmaktadır. Gacar ve Coşkuner (2010) tarafından yapılan çalışmada, 12. sınıf öğrencilerinin atılganlık düzeyinin 8. sınıf öğrencilerinden daha yüksek olduğunu bulunmuştur. Benzer olarak Menteş (2007) tarafından yapılan çalışmada da atılganlık düzeyinin sınıf değişkenine göre farklılaştığı bulunmuş, buna göre sınıf düzeyi 
arttıkça atılganlık seviyesinin de arttığı görülmüştür.Yapılan bazı çalışmalarda da (Dinçer ve Öztunç, 2009; Ekinci ve diğ., 2013; Tan ve Aldemir, 2012; Uğurluoğlu, 1996), öğrencilerin atılganlık puanlarının sınıf değişkenine göre anlamlı farklılık göstermediği saptanmıştır.

Elde edilen bulgulara göre, ergenlerin atılganlık düzeyleri yaş değişkenine göre anlamlı farklılık göstermiştir (Tablo 3). Kimble, Marsh ve Kıska (1984),yaptıkları çalışmada yaşça büyük olanların daha atılgan oldukları bulunmuş, yaşın ve deneyimin bu sonuç üzerinde etkili olduğu vurgulanmıştır. Pardeck ve arkadaşları (1991),yaptıkları çalışmada yaş değişkeni ile atılganlık arasında önemli ilişki olduğu ve bizim bulgularımıza paralel olarak yaşça büyük öğrencilerin küçük öğrencilerden daha atılgan oldukları bulgulanmıştır. Alanyazın incelendiğinde yaş faktörünün atılganlığı etkileyen önemli bir değişken olduğunu ortaya koyan çok sayıda çalışma olduğu görülmektedir. Gacar ve Coşkuner'in (2010) yaptığı çalışmada, 1617 yaş grubundakilerin atılganlık puanlarının 13-15 yaş grubundakilerden anlamlı düzeyde daha yüksek olduğu bulunmuştur. Araştırmacılar, yaşın atılganlığı etkileyen önemli bir faktör olduğunu ve atılganlığın içinde bulunulan yaş döneminin gelişimsel özelliklerinden etkilendiğini vurgulamışlardır. Benzer olarak Coşkuner ve arkadaşları (2013) tarafından yapılan çalışmada da atılganlık puanlarının yaşa göre anlamlı farklılık gösterdiği, 18-20 yaş grubundakilerin diğer gruplara oranla daha yüksek atılganlık puanına sahip olduğu görülmüştür. Anlamlı farklılığın ortaya çıktığı diğer bir çalışma da Sünbül ve Yılmaz (2008) tarafından yapılmıştır. Yaş arttıkça atılganlığın da arttığının tespit edildiği bu çalışmaya göre, öğrencilerin sosyal, bilişsel ve yaşla birlikte artan öğrenim yaşantıları geliştikçe ve zenginleştikçe atılganlık düzeylerinin arttığı sonucuna varılmıştır. Yapılan bazı çalışmalarda (Abakay ve diğ., 2017; Çam ve diğ., 2010; Güven, 2010; Yaycı ve Düşmez, 2016), atılganlık puanlarının yaşa göre anlamlı farklılık göstermediği görülmüştür. 
Araştırmada, ergenlerin atılganlık düzeyleri ile sürekli kaygı düzeyleri arasında negatif yönde istatistiksel olarak anlamlı düzeyde ilişki olduğu saptanmıştır (Tablo 4).Bu bulgu; Percell, Berwick ve Beigel'in (1974) atılganlık ve kaygı arasında negatif ilişki olduğu, atılganlık eğitiminin kaygıyı azalttı̆̆ı yönündeki bulgularını desteklemektedir. Araştırmalar, yüksek atılganlık düzeyine sahip bireylerin anlamlı olarak daha az kaygılı olduğunu ve kaygı düzeyi yüksek olanlardan daha atılgan olduklarını ortaya koymuştur. Kaygının azalması öğrencide sosyal olarak kabul edilebilir hak ve duyguların ifadesini kapsayan atılgan davranış1 kazandırmayı kolaylaştırmaktadır. Jakubowski-Spector (1973), atılganlık eğitimi alan yetişkinlerin daha az kaygılı olduklarını ve birbirleriyle olan ilişkilerinin geliştiğini saptamıştır. Atılganlık eğitiminin kaygıyı düşürdüğü yönünde bulgu veren bir başka çalışma da Vehr ve Kaufman (1987) tarafından yapılmıştır. Atılganlık eğitiminin sürekli kaygı düzeyi yüksek olan ergenler üzerindeki etkisini belirlemek üzere yapılan bu çalışmada atılganlık eğitiminden geçen grubun kaygı düzeyi daha düşük bulunmuştur. Bu araştırmacılar özellikle atılganlık eğitiminin okullarda kaygıyı azaltmak kadar atılganlığı arttırma aracı olarak da kullanılmasının yararlı olduğunu belirtmişlerdir. Waksman (1984)kaygı ile atılganlık arasındaki ilişkiyi araştırdığı çalışmasında atılganlık seviyesinin kaygıyla ilişkisi olduğunu saptamış ve atılgan davranış geliştiren ergenlerin kaygı düzeylerinde düşme olduğunu gözlemlemiştir.

Ergenlerin atılganlık ve sürekli kaygı düzeylerinin incelendiği bu çalışmada, elde edilen bulgulara göre öğrencilerin atılganlık ve sürekli kaygı düzeyleri arasında anlamlı ilişki olduğu görülmüş; cinsiyet, sınıf, yaş gibi değişkenlerin atılganlık ve kaygı düzeylerini farklı oranlarda etkilediği saptanmıştır. Ergenlerin atılganlık düzeyi arttıkça kaygılarının azalması ergenlerin girişken ve güvengen olarak yetiştirilmesinin, eğitim ortamlarının bu yönde düzenlenmesinin önemini ortaya koymaktadır. Bu iki kavramın birbiri üzerindeki etkisinin daha iyi anlaşılabilmesi için atılganlık ve sürekli kaygı düzeyi arasındaki ilişkilerin değişik çevresel 
faktörlerle birlikte araştırılmasının, daha geniş ve farklı gruplar üzerinde atılganlığın sosyal etkisinin çalışılmasının önemli olduğu düşünülmektedir.

\section{Makalenin Bilimdeki Konumu}

Eğitim Bilimleri Bölümü/ Rehberlik ve Psikolojik Danışma Anabilim Dalı

\section{Makalenin Bilimdeki Özgünlüğü}

Ergenlerin kurdukları ilişkilerde girişken olmaları, sosyal becerilerinin yüksek olması karşılaştıkları koşullara uyumunu kolaylaştırmaktadır. Gittikçe zorlaşan koşullar karşısında ergenlerin kendilerini atılgan biçimde ifade etmesini önleyen nedenlerin ve kaygı alanlarının belirlenmesi, kaygı ve atılgan davranış arasındaki ilişkinin bireysel, ailevi ve toplumsal değişkenler çerçevesinde ele alınıp incelenmesinin önemli olduğu düşünülmektedir. Eğer kaygının farklı etkileri tanımlanabilir ve bunlar ergenin çevresi tarafından kontrol edilebilinirse ergenlerin kendilerine güvenlerini geliştirip, sosyal beceriler kazanmalarına yardımcı olma imkanı artabilir. Elde edilen veriler atılganlığın arttırılması ve kaygının düşürülmesinin ergenlerin günlük yaşamlarındaki uyumunu kolaylaştırdığı ve onların hayatlarında daha etkili olmasını sağladığı yönünde etki yaratmaktadır. Bu çalışmadan elde edilen verilerin alan çalışmacılarına önemli bilgiler sunduğu düşünülmektedir.

\section{Kaynaklar}

Abakay, U., Alıncak, F.ve Ay, S. (2017). Üniversite öğrencilerinin beden algısı ve atılganlık düzeylerinin incelenmesi. Uluslararası Türk Eğitim Bilimleri Dergisi, (9), 12-18.

Adana, F., Aktaş, B., Erdağı, S., Eliş, S., Alkan, H.ve Uluman, Ö. (2009). Hemşirelik ve sağlık memurluğu öğrencilerinin atılganlık düzeylerinin belirlenmesi. Journal Of Anatolia Nursing And Health Sciences, 12(2).

Akboy, R. (1990). Öğretmen adaylarında durumluk-sürekli kayg1 düzeylerinin belirlenip karşılaştırılması ve kaygı alanlarının saptanması. İzmir: DEÜ Buca Eğitim Fakültesi Yayınlart. 
Akyıldız, H. (1987).Normal ve kaygılı ortamlarda kişilerarası çekicilik. (Yayınlanmamış doktora tezi). Ankara Üniversitesi, Sosyal Bilimler Enstitüsü, Ankara.

Alagül, Ö. (2004). Farklı spor branşlarındaki sporcuların atılganlık ile beden algısı ilişkisi. (Yayımlanmamış yüksek lisans tezi). Ege Üniversitesi,Sağlık Bilimleri Enstitüsü, İzmir.

Alberti, R. E.,\& Emmons, M. L. (1986). The professional edition of your perfect right: A manual for assertiveness trainers. Impact Publishers.

Arı. R. (1989). Üniversite öğrencilerinin baskın ben durumları ile bazı özlük niteliklerinin atılganlık ve uyum düzeylerine etkisi.(Yayımlanmamış doktora tezi). Hacettepe Üniversitesi. Sosyal Bilimler Enstitüsü, Ankara.

Boyacı, S. (1990). Teknik ve Endüstri Meslek Lisesi son sınıf öğrencilerinin mesleğe yönelik beklenti ve kaygı düzeyleri üzerine bir araştırma.(Yayımlanmamış yüksek lisans tezi).Dokuz Eylül Üniversitesi, Sosyal Bilimler Enstitüsü, İzmir.

Cooley, E. L., \& Nowicki Jr, S. (1984). Locus of control and assertiveness in male and female college students. The Journal of Psychology, 117(1), 85-87.

Coskuner, Z., Coban, B., Savucu, Y., Gacar, A. ve Genc, E. (2013). A study on assertiveness level of college students who are doing orienteering sports. Advances in Environmental Biology, 725-730.

Çam, İ., Özçelik, İ., Çetin, B., Salman, M. ve Çekin, R . (2010). Celal Bayar Üniversitesi beden eğitimi ve spor yüksekokulu öğrencilerinin değişik demografik özeliklere göre atılganlık düzeylerinin araştırılması. CBÜ Beden Eğitimi ve Spor Bilimleri Dergisi, 5 (2), 46-51.

Del Greco, L., Breitbach, L., Rumer, S., McCarthy, R. H., \& Suissa, S. (1986). Four-year results of a youth smoking prevention program using assertiveness training. Adolescence, 21(83), 631-640.

Delamater, R. J., \&Mcnamara, R. J. (1985). Perceptions of assertiveness by high-and lowassertive female college students. The Journal of Psychology, 119(6), 581-586.

Dinçer, F. ve Öztunç, G. (2009). Hemşirelik ve ebelik öğrencilerinin benlik saygısı ve atılganlık düzeyleri. Hacettepe Üniversitesi Hemşirelik Fakültesi Dergisi, 16(2), 22-33. 
Ekinci, M., Şahin Altun, Ö. ve Can, G. (2013). Hemşirelik öğrencilerinin stresle başa çıkma tarzları ve atılganlık düzeylerinin bazı değişkenler açısından incelenmesi. Psikiyatri Hemşireliği Dergisi, 4(2), 67-74.

Farrell, G. A. (2001). From tall poppies to squashed weeds: why don't nurses pull together more? Journal of Advanced Nursing, 35(1), 26-33.

Gacar, A. ve Coşkuner, Z. (2010). Güreşçilerin atılganlık düzeylerinin bazı değişkenler açısından incelenmesi. Sport Sciences, 5(3), 195-203.

Geçtan, E. (1993). Psikodinamik psikiyatri ve normal dışı davranışlar. Remzi Kitabevi.

Güler, R. (2011). Hemşirelik öğrencilerinin benlik saygısı ve atılganlık düzeyleri.(Yayınlanmamış yüksek lisans tezi). Yakın Doğu Üniversitesi, Sağlık Bilimleri Fakültesi, Lefkoşa.

Güven, M. (2010). An analysis of the vocational education undergraduate students' levels of assertiveness and problem-solving skills. Procedia-Social and Behavioral Sciences, 2(2), 2064-2070.

Hurt, V. K. (1986). The effect of assertiveness training on the agressi-ve behavior, self concept, locus of control and classroom behavior delinquent adolescent males. Dissertation Abstracts, 47(2), 773-774.

Jakubowski-Spector, P. (1973). An introduction to assertive training procedures for women. Washington, DC: American Personnel Guidance Association Press.

Kapıkıran, Ş. (1993). İçten ve dıştan denetimliliğe sahip ergenlerin atılganlık düzeyinin saptanması.(Yayımlanmamış yüksek lisans tezi). Dokuz Eylül Üniversitesi, Sosyal Bilimler Enstitüsü, İzmir.

Kaya, Z., İkiz, F. E. Ve Asıcı, E. (2016). Fen lisesi öğrencilerinin problemli internet kullanımı ile psikolojik semptomları arasındaki ilişkinin incelenmesi. (Investigation of the relationship between problematic internet use and psychological symptoms of science high school students). International Journal of Human Sciences, 13(1), 451-465.

Kessler, G. R., Ibrahim, F. A., \& Kahn, H. (1986). Character development in adolescents. Adolescence, 21(81), 1-9. 
Kilkus. S. P. (1993). Assertiveness among professional nurses. Journal of Advanced Nursing. (18), 1324-1330.

Kırımoğlu, H. (2008). Türkiye 13 yaş altı badminton şampiyonasına katılan sporcu öğrenciler ile sporcu olmayan öğrencilerin atılganlık düzeylerinin karşılaştırılması. Selçuk Üniversitesi Beden Eğitimi ve Spor Dergisi, 10(2), 1-9.

Kırımoğlu, H., Kepoğlu, A., Dereceli, Ç., Parlak, N. ve Tozoğlu, E. (2009). İlköğretim II. kademe öğrencilerinin atılganlık düzeylerinin spora katılımları bakımından incelenmesi (Ankara-Elmadağ ilçesi örneği). Atatürk Üniversitesi Beden Ĕgitimi ve Spor Bilimleri Dergisi, 11(1), 7-15.

Kimble, C. E., Marsh, N.B., \& Kiska, A. C. (1984). Sex, age and cultural differences in selfreported assertiveness. Psychological Reports. 55(2), 419-422.

Lazarus, A. A. (1973). On assertive behavior: A brief note. Behavior therapy, 4(5), 697-699.

Menteş, A. (2007). Lise öğrencilerinin atılganlık düzeyine sporun etkisi.(Yayımlanmamış yüksek lisans tezi). Gazi Üniversitesi, Eğitim Bilimleri Enstitüsü, Ankara.

Nacar, E., İmamoğlu, O., Karahüseyinoğlu, M. F. ve Açak, M. (2011). Hentbolcuların sürekli kaygı düzeylerinin bazı değişkenler açısından araştırılması. Sport Sciences, 6(1), 1-12.

Onur, B. (1993). Çocuk ve ergen gelişimi. Ankara: İmge Kitabevi.

Öner, N. (2006). Türkiye'de kullanılan psikolojik testlerden örnekler.(2. Baskı). Boğaziçi Üniversitesi Yayınları.

Öner, N. ve Le Compte, A. (1983). Durumluluk ve sürekli kaygı envanteri el kitab1 [Handbook of state and trait anxiety inventory]. İstanbul: Boğaziçi Üniversitesi Yayınları, 1-26.

Öztürk, M.O. (1994). Ruh să̆lı̆̆l ve bozuklukları (Yenilenmiş 5. Baskı). Ankara, Hekimler Yayın Birliği.

Pardeck. J.T., Anderson. C., Giannino. E. A., Miller. B., Mothershead. M.S., \& Smith. S.A. (1991). Assertiveness of social work students. Psychological Reports. (69), 589-590.

Percell, L. P., Berwick, P. T., \& Beigel, A. (1974). The effects of assertive training on selfconcept and anxiety. Archives of General Psychiatry, 31(4), 502-504.

Rathus, S. A. (1973). A 30 item schedule for assesing assertive. Behavior Therapy. 4, 398-406.

Ray, J. J. (1986). Assertiveness as authoritarianism and dominance. The Journal of social psychology, 126(6), 809-810. 
Russel, G., \& Russel, A. (1987). Mother-child and father-child relationships in middle childhood. Child Development, 58(6), 1573-1585.

Sargın, N. (1990). Lise I. ve Lise III. sınıf öğrencilerinin durumluk sürekli kaygı düzeylerinin belirlenip karşılaştırılması. (Yayınlanmamış yüksek lisans tezi). Dokuz Eylül Üniversitesi, Sosyal Bilimler Enstitüsü, İzmir.

Smith, M. J. (1998). Hayır dediğimde kendimi suçlu hissediyorum. (çev. Gülden Güvenç). Ankara: HYB yayıncılık.

Spielberg, C. D., Gorsuch, R. L., \& Lushene, R. E. (1970). Manual for the state-trait anxiety inventory. California: Consulting Psychologists Press.

Sünbül, A. ve Yılmaz, E. (2008, Mayıs). Üniversite öğrencilerinin girişimcilik ve atılganlık düzeyleri arasındaki ilişkinin incelenmesi. 2. Uluslararası Girişimcilik Kongresi, 7-10 Mayıs. Bişkek, 494-498.

Şahin, D. ve Güvenç, G. B. (1996). Ergenlerde aile alg1s1 ve benlik alg1s1. Türk Psikoloji Dergisi, 11 (38), 22-32.

Tan, S. ve Aldemir, S. (2012). Ergenlerde stresle başa çıkma tarzlarının atılganlık düzeyleri ve sosyo-demografik özellikler açısından incelenmesi. New/Yeni Symposium Journal, 50 (1).

Tegin. B. (1990). Üniversite öğrencilerinin atılganlık davranışının ve eğilimlerinin cinsiyet ve fakülte değişkeni açısından incelenmesi. Türk Psikoloji Dergisi. 7 (25), 21-32.

Top, F. Ü. ve Kaya, B. (2009). Sağlık bilimleri fakültesi öğrencilerinin benlik saygıları ve atılganlık düzeylerinin sosyodemografik özellikleri açısından incelenmesi.New/Yeni Symposium Journal, 47 (4).

Tucker, R. K., Weaver, R. L., \& Redden, E. M. (1983). Differentiating assertiveness, aggressiveness, and shyness: a factor analysis. Psychological reports, 53(2), 607-611.

Uğurluoğlu, Y. M. (1996). Lise öğrencilerinde özsaygı düzeyi ile atılgan kişilik özelliği arasındaki ilişkinin incelenmesi.(Yayımlanmamış yüksek lisans tezi). Karadeniz Teknik Üniversitesi, Sosyal Bilimler Enstitüsü, Trabzon.

Üstün, B. (1995). Hemşirelerin atılganlık ve tükenmişlik düzeyleri.(Yayımlanmamış doktora tezi). Hacettepe Üniversitesi, Sosyal Bilimler Enstitüsü, Ankara.

Vanbeleare, N. (1996). Gruplar arası davranışın sosyal psikolojik analizi: bireyci bir yaklaşımdan sosyal kimlik yaklaşımına. (çev. Arkonaç, S.A). IX. Ulusal Psikoloji Kongresi Bilimsel Çalışmalar. Türk Psikoloji Derneği Yayınları, 45-71. 
Voltan, N. (1980). Rathus Atılganlık Envanteri geçerlik ve güvenirlik çalışması. Türk Psikoloji Dergisi, (10), 23-25.

Voltan-Acar, N. ve Whirter, M. J. (2000). Ergen ve çocukla iletişim. Ankara: USA Yayıncılık. Waksman, S. A. (1984). Assertion training with adolescents. Adolescence, 19(73), 123-130.

Wehr, S. H., \& Kaufman, M. E. (1987). The effects of assertive training on performance in highly anxious adolescents. Adolescence, 22(85), 195.

Williams, J. M., \& Stout, J. K. (1985). The effect of high and low assertiveness on locus of control and health problems. The Journal of Psychology: Interdisciplinary and Applied. 119(2), 169-173.

Wills, T. A., Baker, E., \& Botvin, G. J. (1989). Dimensions of assertiveness: Differential relationships to substance use in early adolescence. Journal of Consulting and Clinical Psychology, 57(4), 473-478.

Yanbastı, G. (1994). Kişilik kuramları. Ege Üniversitesi Edebiyat Fakültesi Yayını. No:53, İzmir.

Yayc1, L. ve Düşmez, İ. (2016).Üniversite öğrencilerinin cinsiyet rolleri tutumları ve atılganlık düzeylerinin bazı demografik özelliklere göre incelenmesi. Erzincan Üniversitesi Eğitim Fakültesi Dergisi, 18(1), 34-62.

Yılmaz, E. ve Sünbül, A. M. (2009). Üniversite öğrencilerine yönelik girişimcilik ölçeğinin geliştirilmesi. Selçuk Üniversitesi Sosyal Bilimler Enstitüsü Dergisi, (21), 195-203. 


\section{Summary}

\section{Problem Statement}

Understanding and explaining human behavior is one of the basic subjects of psychology as a behavior science. As behavior is considered as a reflection of personality, behavior pattern is accepted as a indicator of the tendencies of an individual's personality. Individuals who are unable to present themselves in interpersonal relationships and who cannot claim their rights have been studied by behaviorist therapy since Wolpe (1958) and Salter (1949). Assertiveness training had primarily aimed to protect the individual rights of people with certain personality characters. In this regard, it had found a place in therapy setting to help those individuals become more effective in their lives (as cited in K1lkus, 1993). As a result assertiveness was conceptualized based on some questions such as: What are the reasons that make some individuals assertive and some unconfident? Is assertiveness training helpful for people to function more effectively in their everyday lives? Anxiety is one of the basic emotions experienced by individuals in multiple settings of interpersonal relationships. Anxiety is defined as the reaction that one experiences during periods of inhabited life and in times of insecurity, instability, and conflict that are shaped by the thought of encountering events that are presentor in the future (Akyıldı, 1987).Although there are numerous studies of assertiveness and anxiety in the literature, there are limited studies that investigate both concepts together. Determining the inhibiting factors and anxiety domains that affect adolescents to express themselves assertively, and investigating the relation between anxiety and assertiveness within the frame of individual and social variables are thought to increase the interpersonal compatibility and efficiency of adolescents. In order to enhance the self-esteem of adolescents, and help them to gain social skills, the different effects of anxiety should be determined and controlled.

\section{Purpose of the Study}

The present study aims to explain the relationship between the assertiveness and anxiety levels of adolescents and to investigate whether they differ based on certain variables such as gender, grade, department, age and so on. 


\section{Method}

The present study is based on relational screening modeling which aims to explore the presence and level of correlations between two or more variables. The participants were enrolled in five different vocational high schools in İzmir. Of 366 participants, 189 (51.6 \%) were female and 177 (48.4\%) were male. Rathus Assertiveness Inventory, Trait Anxiety Inventory and Demographic Information Form were used for data collection. Descriptive statistics (frequencies, means, and standard deviations), correlation, t-test and one-way ANOVA and regression analyses were used. In group comparisons, groups were combined together when the number of students was not efficient for in group comparisons.

\section{Findings and Discussions}

The participants have low levels of assertiveness and moderate levels of trait anxiety in the present study. The result of anxiety levels above normal is related to the developmental characteristics of adolescents. Adolescence is the period of gaining autonomy. Therefore, adolescents are expected to acquire certain skills for adulthood. Anxiety can be considered as an accompanying emotion. There was a significant negative correlation between adolescents' assertiveness and trait anxiety levels. This finding is similar to the results presented by Percell, Berwick, and Beigel (1974) that showed a negative correlation between assertiveness and anxiety, and assertiveness training increased the anxiety levels. Numerous studies (Jakubowski-Spector, 1973; Waksman, 1984; Vehr and Kaufman, 1987) indicated higher assertiveness level resulted in lower levels of anxiety, and assertiveness training is an important tool for increasing anxiety. Assertiveness levels of adolescents have not shown significant differences based on gender. The literature review showed conflicted results. According to the studies they show no significant difference based on gender (Cam et al., 2010; Sunbul and Y1lmaz, 2008; Tan and Aldemir, 2012; Tegin, 1990; Yayc1 and Düsmez, 2016; Y1lmaz and 
Sunbul, 2009), the indifference of assertiveness levels between females and males are seen as a result of women's ability to advocate their rights, to express themselves and to show assertive behaviors such as self-esteem. With the rapidly changing social structure, women began to be more predominant in social life and have equal educational rights (Alagul, 2004; Y1lmaz and Sunbul, 2009). Adolescents' anxiety levels showed significant gender differences. Females were found to have higher anxiety levels compared to males. Similar results were found in previous studies (Akboy, 1990; Sargin, 1990; Boyaci, 1990). The assertive levels of the students were also found to differ significantly based on grade and age. As grades and age increase, so the assertiveness levels. This result is thought to be related to the fact that as age increases, individuals gain more information and experience about life.

\section{Conclusions and Recommendations}

In the present study that investigated the assertiveness and trait anxiety levels of adolescents, the results indicated a significant correlation between assertiveness and trait anxiety levels. Moreover, variables such as gender, grade and age affect assertiveness and trait anxiety levels of students to different extents. As assertiveness levels increase, anxiety levels decrease. This indicates the importance of the regulation of school setting accordingly. For a more clear understanding of the reciprocal relationship between these two concepts, the relationship between assertiveness and trait anxiety should be examined with different environmental factors. The social effects of assertiveness should be investigated on larger and diverse groups. Finally, the awareness of the individuals who have a role in the education of adolescents should be raised on the importance of assertiveness. 